\title{
Pengaruh Penerapan E-Filing pada Kepatuhan WPOP dengan Sosialisasi Perpajakan dan Pemahaman Internet sebagai Variabel Pemoderasi
}

\author{
Putu Laksmi Puspita Yanti ${ }^{1}$ \\ Fakultas Ekonomi dan Bisnis \\ Universitas Udayana, Indonesia
}

\author{
Putu Ery Setiawan ${ }^{2}$ \\ Fakultas Ekonomi dan Bisnis \\ Universitas Udayana, Indonesia
}

\begin{abstract}
Surel : laksmipuspitaa@gmail.com
ABSTRAK

Penelitian ini bertujuan untuk mengetahui pengaruh penerapan e-filing pada kepatuhan Wajib Pajak Orang Pribadi di KPP Pratama Badung Utara dengan sosialisasi perpajakan dan pemahaman internet dengan variabel pemoderasi. Jumlah sampel yang digunakan dalam penelitian ini adalah sebanyak 100 responden dari 26.624 populasi Wajib Pajak Orang Pribadi. Teknik analisis data yang digunakan adalah uji regresi linear sederhana dan uji interaksi Moderated Regression Analysis (MRA). Berdasarkan hasil analisis, penerapan e-filing berpengaruh positif dan signifikan pada kepatuhan Wajib Pajak Orang Pribadi di KPP Pratama Badung Utara. Sosialisasi perpajakan dan pemahaman internet tidak dapat memoderasi pengaruh penerapan e-filing pada kepatuhan Wajib Orang Pribadi di KPP Pratama Badung.
\end{abstract}

Kata Kunci: E-Filing; Sosialisasi Perpajakan; Pemahaman Internet; Kepatuhan Wajib Pajak Orang Pribadi.

The Effect of E-Filing Application on the Compliance of Individual Taxpayers with Tax Socialization and Internet Understanding as Moderating Variables

ABSTRACT

This study aims to determine the effect of the application of e-filing on compliance of individual taxpayers in North Badung Primary Tax Office with tax dissemination and internet understanding as moderating variables. The number of samples used in this study were 100 respondents out of 26,624 populations of individual taxpayers in North Badung Primary Tax Office in 2019. The data analysis technique used are simple linear regression test and the Moderated Regression Analysis (MRA) interaction test. The results showed that the application of e-filing has a positive and significant effect on the compliance of individual taxpayers in North Badung Primary Tax Office. Tax socialization and internet understanding was not able to moderate the effect of implementing e-filing on the Obligatory Compliance of Individuals in North Badung Primary Tax Office.

Keywords: $\quad$ E-Filing; Tax Dissemination; Internet Understanding; Personal Taxpayer Compliance.

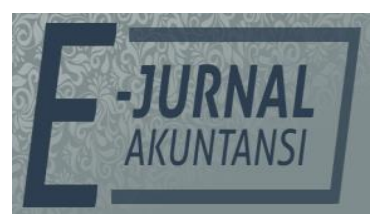

e-ISSN 2302-8556

Vol. 30 No. 8

Denpasar, Agustus 2020

Hal. 1900-1914

10.24843/EJA.2020.v30.i08.p01

PENGUTIPAN:

Yanti, P. L. P \& Setiawan, P. E. (2020). Pengaruh Penerapan EFiling pada Kepatuhan WPOP dengan Sosialisasi Perpajakan dan Pemahaman Internet sebagai Variabel Pemoderasi. EJurnal Akuntansi, 30(8), 1900-

1914

RIWAYAT ARTIKEL:

Artikel Masuk: 19 Januari 2020

Artikel Diterima: 13 Maret 2020

Artikel dapat diakses : https://ojs.unud.ac.id/index.php/Akuntansi/index 


\section{PENDAHULUAN}

Salah satu sumber penerimaan terbesar sebuah negara adalah berasal dari sektor pajak. Untuk itu, dalam rangka menunjang pembiayaan, optimalisasi penerimaan negara sangat penting bagi pemerintah dan pembangunan nasional. Chau \& Leung (2009) berpendapat bahwa faktor yang mempengaruhi penerimaan pajak suatu negara diantaranya adalah tingkat kepatuhan Wajib Pajak masyarakat di negara tersebut. Masalah kepatuhan Wajib Pajak adalah masalah yang penting di seluruh dunia, baik itu di negara maju maupun di negara berkembang, karena jika Wajib Pajak tidak patuh maka akan menimbulkan keinginan untuk melakukan tindakan penghindaran, pengelakan dan pelalaian pajak. Saat ini bila pajak tidak dipatuhi dan dipenuhi pembayarannya oleh Wajib Pajak maka pemerintah tidak dapat berjalan dengan baik (Hammar \& Nordblom, 2009)

Paramartha \& Rasmini (2019) menjelaskan bahwa Pajak sebagai pemberi kontribusi terbesar dalam penerimaan negara mempunyai dampak yang sangat besar bagi kelangsungan pembangunan negara ini, walaupun masih ada sektorsektor lain yang juga memberikan kontribusinya dalam penerimaan negara. Kepatuhan merupakan istilah paling netral dan inklusif yang menggambarkan ketersediaan orang untuk membayar pajak (Kirchler \& Wahl, 2010). Mengingat pentingnya peranan pajak sebagai sarana pembangunan negara, penerimaaan pajak sebuah negara akan bergantung dari kepatuhan membayar pajak warga negaranya. Konsep kepatuhan Wajib Pajak didefinisikan sebagai sikap positif yang timbul dari dalam diri individu dalam kesadarannya untuk membayar pajak (Helhel \& Ahmed, 2014). Kepatuhan dalam Wajib Pajak dapat dikatakan sebagai kepatuhan dalam persyaratan pelaporan pajak dimana Wajib Pajak mengajukan dan melaporkan kewajibannya sesuai dengan peraturan yang berlaku (Devos, 2009). Namun, hal ini masih belum berlaku pada Wajib Pajak Orang Pribadi di wilayah Badung Utara. Hal tersebut dapat dilihat pada Tabel 1, Rasio Kepatuhan Wajib Pajak Orang Pribadi (WPOP) di KPP Pratama Badung Utara Tahun 2015-2019.

Tabel 1. Rasio Kepatuhan Wajib Pajak Orang Pribadi (WPOP) di KPP Pratama Badung Utara Tahun 2015-2019

\begin{tabular}{lllll}
\hline No & Tahun & $\begin{array}{c}\text { WPOP } \\
\text { Efektif }\end{array}$ & $\begin{array}{c}\text { WPOP yang } \\
\text { menyampaikan SPT }\end{array}$ & $\begin{array}{c}\text { Rasio } \\
\text { Kepatuhan (\%) }\end{array}$ \\
\hline 1 & 2015 & 53.953 & 26.149 & 48,47 \\
2 & 2016 & 57.473 & 27.132 & 47.21 \\
3 & 2017 & 61.082 & 27.591 & 45.17 \\
4 & 2018 & 64.711 & 27.405 & 42.34 \\
5 & 2019 per 31 & 69.676 & 28.251 & 40.54 \\
& Desember & & & \\
\hline
\end{tabular}

${ }^{*}$ Rasio Kepatuhan = SPT WPOP Masuk/WPOP Terdaftar

Sumber: Data Penelitian, 2019

Berdasarkan Tabel 1, Rasio Kepatuhan Wajib Pajak Orang Pribadi (WPOP) di KPP Pratama Badung Utara Tahun 2015-2019 dapat dilihat bahwa Rasio Kepatuhan Wajib Pajak Orang Pribadi (WPOP) di KPP Pratama Badung Utara pada tahun 2015-2019 mengalami penurunan rasio kepatuhan setiap tahunnya. Ini berarti tingkat kepatuhan Wajib Pajak akan mematuhi pemenuhan 
kewajiban dalam membayar pajaknya semakin menurun. Kepatuhan Wajib Pajak mengacu pada pemenuhan kewajiban perpajakan sebagaimana ditentukan oleh undang-undang yang berlaku dan dilakukan oleh pembayar pajak dala rangka memberika kontribusi bagi negara yang diharapkan didalam pemenuhannya secara sukarela (Serem \& Robert, 2017).

Dewi \& Noviari (2018) dalam penelitiannya menyatakan bahwa terdapat dua faktor yang mempengaruhi kepatuhan Wajib Pajak yakni faktor internal dan faktor eksternal. Perilaku yang disebabkan secara internal adalah perilaku yang diyakini berada di bawah kendali pribadi individu itu sendiri atau berasal dari faktor internal seperti ciri kepribadian, kesadaran, dan kemampuan. Sedangkan, perilaku yang disebabkan secara eksternal adalah perilaku yang dipengaruhi dari luar atau dari faktor eksternal seperti peralatan atau pengaruh sosial dari orang lain, artinya individu akan terpaksa berperilaku karena situasi (Manuaba \& Gayatri, 2017). Sistem perpajakan modern dapat digolongkan sebagai faktor eksternal yang mempengaruhi Wajib Pajak untuk melaksanakan perpajakannya (Ameur \& Tkiouat, 2016).

Reformasi administrasi perpajakan modern sangat perlu dilakukan oleh Direktorat Jenderal Pajak dalam rangka semakin meningkatkan pelayanan kepada Wajib Pajak. Sistem administrasi modern adalah sistem administrasi yang mengalami penyempurnaan atau perbaikan untuk meningkatkan pelayanan kepada Wajib Pajak dengan memanfaatkan teknologi informasi yang diharapkan dapat meningkatkan kepatuhan Wajib Pajak dan penerimaan pajak (Walsh, 2012). Dengan reformasi administrasi perpajakan, berbagai fasilitas untuk kemudahan dan kenyamanan pelayanan kepada Wajib Pajak dilakukan dengan mengoptimalkan pemanfaatan perkembangan dan kemajuan tekhnologi informasi dengan menerapkan sistem e-filing. E-Filing adalah saluran baru untuk membayar pajak melalui media elektronik seperti internet (Anees \& Kumar, 2017).

Dengan diterapkannya sistem e-filing, diharapkan sistem baru ini akan dapat memberikan kenyamanan dan kemudahan bagi Wajib Pajak dalam mempersiapkan dan menyampaikan SPT, karena dapat dikirimkan kapan saja dan dimana saja sehingga dapat meminimalkan biaya dan waktu yang digunakan Wajib Pajak untuk penghitungan, pengisian dan penyampaian SPT. Namun fenomena saat ini, mayoritas Wajib Pajak masih banyak yang belum mengaplikasikan sistem e-filing. Hal tersebut dilandaskan sosialisasi dari Direktorat Jenderal Pajak mengenai e-filing yang minim dan menyebabkan rendahnya pengetahuan Wajib Pajak mengenai penerapan pelaporan pajak menggunakan teknologi baru (internet) untuk melaporkan pajaknya. Sehingga Wajib Pajak berasumsi bahwa menggunakan e-filing akan lebih susah dari pada dengan manual. Sosialisasi perpajakan adalah upaya yang dilakukan oleh Dirjen Pajak untuk memberikan sebuah pengetahuan kepada masyarakat dan khususnya Wajib Pajak agar mengetahui tentang segala hal mengenai perpajakan baik peraturan maupun tata cara perpajakan melalui metode-metode yang tepat (Handayani \& Tambun, 2016).

Sosialisasi perpajakan sangat penting diberikan kepada Wajib Pajak dalam memenuhi kewajiban perpajakannya. Kesadaran Wajib Pajak akan lebih efektif jika Direktorat Jenderal Pajak mengadakan sosialisasi perpajakan. Adanya 
sosialisasi perpajakan ini, maka Wajib Pajak akan mendapatkan pengertian, informasi, dan pembinaan sehingga dapat meningkatkan kesadaran Wajib Pajak (Suriambawa \& Setiawan, 2018). Sosialisasi perpajakan dilakukan untuk memberikan informasi yang baik dan benar sehingga Wajib Pajak akan memiliki pengetahuan tentang arti pentingnya membayar pajak dan pada akhirnya akan meningkatkan kepatuhan Wajib Pajak. Jika sosialisasi perpajakan disampaikan dengan jelas, benar, dan nyaman oleh petugas pajak, maka Wajib Pajak akan memiliki pengetahuan tentang arti pentingnya membayar pajak yang secara otomatis akan meningkatkan kepatuhan Wajib Pajak (Wardani \& Wati, 2018).

Dengan diberlakukannya sistem administrasi modern dengan penerapan sistem e-filing, dibutuhkan adanya pemahaman internet yang baik dalam mendukung penggunaan sistem e-filing. Untuk dapat menggunakan sistem tersebut, Wajib Pajak dituntut untuk mengerti atau paham terhadap internet, yaitu mengetahui bagaimana cara mengoperasikan internet. Hal ini juga menjadi faktor penting bagi Wajib Pajak dalam menggunakan e-filing, karena dengan pemahaman internet yang baik, maka akan semakin tinggi pula keinginan Wajib Pajak dalam menggunakan e-filing serta akan meningkatkan tingkat kepatuhan Wajib Pajak dalam melaporkan pajaknya.

Teori perilaku yang direncanakan (Theory of Planned Behavior), menjelaskan bahwa sikap terhadap perilaku merupakan pokok penting yang sanggup memperkirakan suatu perbuatan, meskipun demikian perlu dipertimbangkan sikap seseorang dalam menguji norma subjektif serta mengukur kontrol perilaku persepsian orang tersebut. Bila ada sikap yang positif, dukungan dari orang sekitar serta adanya persepsi kemudahan karena tidak ada hambatan untuk berperilaku maka niat seseorang untuk berperilaku akan semakin tinggi. Faktor utama dari perilaku individu adalah perilaku yang dipengaruhi oleh niat individu (behavior intention) terhadap perilaku tertentu tersebut. Kebiasaan dianggap dapat melihat faktor-faktor motivasi yang mempengaruhi perilaku individu dalam melakukan sesuatu, individu tersebut akan memiliki keyakinan mengenai hasil yang akan diperoleh dari perilakunya tersebut. Kemudian yang bersangkutan akan memutuskan bahwa akan melakukannya atau tidak melakukannya. Hal tersebut berkaitan dengan kesadaran wajib pajak (Suriambawa \& Setiawan, 2018).

Teori Model Penerimaan Teknologi (Technology Acceptence Model) adalah suatu model untuk memprediksi dan menjelaskan bagaimana pengguna teknologi menerima dan menggunakan teknologi tersebut dalam pekerjaan individual pengguna. (Venkatesh \& Davis, 2000). Menurut Gefen (2003) TAM merupakan model yang paling banyak digunakan dalam memprediksi penerimaan teknologi informasi. Teori TAM dengan persepsi kemudahan penggunaan (ease to use) dan persepsi kemanfaatan (usefulness) dapat menjelaskan pengaruh penerimaan sistem informasi (Pranata \& Supadmi, 2018). Berdasarkan teori TAM, Davis, et al., (2003) menyatakan bahwa persepsi kemudahan dan persepsi kegunaan adalah yang akan menjadi penentu dari suatu sistem dapat diterima atau tidak. Wajib Pajak yang beranggapan bahwa sistem e-filing itu mudah digunakan dan Wajib Pajak percaya bahwa menggunakan sistem e-filing akan membantu dalam penyerahan SPT maka hal ini akan meningkatkan kepatuhan Wajib Pajak dalam melaporkan SPT. 
Adapun penelitian sebelumnya yang dilakukan oleh Marliana, et al., (2017), Lado \& Budiantara (2018) dan Sari \& Erawati (2018) menyatakan bahwa penerapan e-filing berpengaruh positif dan signifikan pada kepatuhan Wajib Pajak Orang Pribadi. Penelitian tersebut sejalan dengan penelitian yang dilakukan oleh Agustiningsih (2016) yang menyatakan bahwa penerapan e-filing berpengaruh positif pada Kepatuhan Wajib Pajak Orang Pribadi. Berdasarkan uraian tersebut, dapat dirumuskan hipotesis pertama, yaitu.

$\mathrm{H}_{1}$ : Penerapan e-filing berpengaruh positif pada kepatuhan Wajib Pajak Orang Pribadi di KPP Pratama Badung Utara.

Berdasarkan Theory of Planned Behavior, teori ini menjelaskan bahwa perilaku individu untuk tidak patuh terhadap ketentuan perpajakan ditentukan oleh niat. Fokus utama dari Theory of Planned Behavior, yaitu kebiasaan individu untuk melakukan suatu perilaku tertentu. Kebiasaan dianggap dapat melihat faktor-faktor motivasi yang mempengaruhi perilaku individu. Sosialisasi perpajakan dalam Theory of Planned Behavior merupakan faktor eksternal yang dapat memberikan pengaruh kepada perilaku Wajib Pajak untuk memenuhi kewajibannya. Dengan adanya niat dan motivasi dari individu hal ini dapat merubah perilaku individu itu sendiri khususnya Wajib Pajak untuk dapat menerima informasi tentang sistem dan peraturan perpajakan yang berlaku baik yang diterima melalui sosialisasi perpajakan secara langsung maupun tidak langsung. Ketika Wajib Pajak telah mendapatkan sosialisasi perpajakan maka hal ini dapat membantu dalam merubah perilaku Wajib Pajak serta dapat menumbuhkan motivasi Wajib Pajak dalam menggunakan sistem e-filing, maka Wajib Pajak akan dapat meningkatkan kepatuhannya dalam memenuhi kewajibannya sebagai Wajib Pajak yang dikarenakan oleh niat Wajib Pajak untuk memenuhi kewajiban perpajakannya dan kemudian niat tersebut direalisasikan.

Hasil penelitian yang dilakukan oleh Ismail \& Amalo (2018) dan Suriambawa \& Setiawan (2018) menyatakan bahwa sosialisasi perpajakan memperkuat pengaruh penerapan sistem e-filing pada kepatuhan Wajib Pajak. Namun, hasil yang berbeda diperoleh oleh Setiyarini \& Mohklas (2017), Gustiari \& Suprasto (2018) dan Handayani \& Tambun (2016) yang menyatakan bahwa sosialisasi perpajakan tidak dapat memoderasi pengaruh hubungan penerapan sistem e-filing pada kepatuhan wajib pajak. Berdasarkan uraian tersebut, dapat dirumuskan hipotesis kedua, yaitu.

$\mathrm{H}_{2}$ : Sosialisasi perpajakan memperkuat pengaruh penerapan e-filing pada kepatuhan Wajib Pajak Orang Pribadi di KPP Pratama Badung Utara.

Berdasarkan Theory Planned of Behaviour, sikap terhadap perilaku merupakan pokok penting yang sanggup memperkirakan suatu perbuatan, meskipun demikian perlu dipertimbangkan sikap seseorang dalam menguji norma subjektif serta mengukur kontrol perilaku persepsian orang tersebut. Internet menjadi salah satu media pendukung dari sistem $e$-filing, dimana dalam penerapan dan penggunaan sistem e-filing, dibutuhkan pemahaman internet yang baik. Hal ini juga menjadi faktor penting Wajib Pajak untuk menggunakan e-filing, karena dengan pemahaman internet yang baik semakin tinggi pula keinginan Wajib Pajak dalam menggunakan e-filing. Ketika Wajib Pajak paham terhadap internet maka mereka dapat menggunakan internet tersebut untuk mencari informasi secara luas mengenai sistem $e$-filing, sehingga dapat merubah 
pola berfikir mereka. Jika Wajib Pajak paham terhadap penggunaan internet, maka hal itu akan dapat membantu mereka dalam mengoperasikan sistem $e^{-}$ filing dengan baik dan benar sehingga hal ini dapat meningkatkan kepatuhan Wajib Pajak.

Penelitian yang dilakukan oleh Mendra (2010), dan Suprayogo \& Hasymi (2018) menunjukkan bahwa Pemahaman internet dapat memperkuat pengaruh penerapan sistem e-filing pada kepatuhan Wajib Pajak. Hasil penelitian yang berbeda diperoleh oleh Agniveda \& Supadmi (2019) dan Lado \& Budiantara (2018) yang menunjukkan pemahaman internet tidak dapat memoderasi pengaruh penerapan sistem e-filing pada kepatuhan Wajib Pajak Orang Pribadi. Berdasarkan uraian tersebut, dapat dirumuskan hipotesis ketiga, yaitu.

$\mathrm{H}_{3}$ : Pemahaman internet memperkuat pengaruh penerapan e-filing pada kepatuhan Wajib Pajak Orang Pribadi di KPP Pratama Badung Utara.

\section{METODE PENELITIAN}

Penelitian ini dilakukan di di Kantor Pelayanan Pajak Pratama Badung Utara. Kantor Pelayanan Pajak Pratama Badung Utara berlokasi di Jalan A. Yani No.100 Denpasar Utara. Objek penerlitian ini adalah kepatuhan Wajib Pajak Orang Pribadi yang terdaftar di KPP Pratama Badung Utara yang dipengaruhi oleh penerapan e-filing dengan sosialisasi perpajakan dan pemahaman internet sebagai variabel pemoderasi.

Populasi dalam penelitian ini adalah jumlah seluruh Wajib Pajak Orang Pribadi efektif yang menggunakan e-filing yang terdaftar pada Kantor Pelayanan Pajak Pratama Badung Utara yang berjumlah 26.624 Wajib Pajak. Jumlah sampel ditentukan dengan rumus Slovin sebagai berikut.

$\mathrm{n}=\frac{N}{1+N e^{2}}$.

Kerangan:

$\mathrm{N}=$ Jumlah populasi

$\mathrm{n}=$ Sampel

$\mathrm{e}^{2}=$ Persen kesalahan pengambilan sampel (batas ketelitian 0,1)

Berdasarkan data yang diperoleh dari KPP Pratama Badung Utara, diketahui jumlah populasi Wajib Pajak Orang Pribadi efektif yang terdaftar menggunakan e-filing per 31 Desember 2019 adalah sebanyak 26.624 orang. Dengan menggunakan rumus Slovin, maka besarnya sampel penelitian adalah.

$\mathrm{n}=\frac{26.624}{1+26.624(0,1)^{2}}$

$\mathrm{n}=99,63$

$\mathrm{n}=100$ (dibulatkan)

Metode penentuan sampel pada penelitian ini adalah dengan menggunakan non probability sampling dengan teknik sampling insidental. Penelitinan ini menggunakan model analisis regresi linear sederhana dan analisis regresi moderasi Moderated Regression Analysis (MRA). Berdasarkan hasil analisis regresi, selanjutnya diamati mengenai uji kelayakan model (Uji F), uji koefisien determinasi $\left(R^{2}\right)$ dan uji hipotesis (uji t). Namun sebelumnya dilakukan uji instrumen penelitian yang meliputi uji validitas dan uji reabilitas, analisis 
statistic deskriptif dan uji asumsi klasik yang meliputi uji normalitas dan uji heteroskedastisitas.

\section{HASIL DAN PEMBAHASAN}

Kuisioner yang disebar dalam penelitian ini sebanyak 100 kuisioner. Berdasarkan data yang diperoleh, dapat disimpukan bahwa karakteristik responden adalah laki laki yang mayoritas berusia diatas 50 tahun. Tingkat pendidikan terakhir yang mendominasi adalah pada tingkat Strata 1 (S1). Mayoritas responden berkerja sebagai Pegawai Negri Sipil (PNS).

Uji validitas digunakan untuk mengukur valid tidaknya suatu kuisioner. Instrumen penelitian dikatakan valid apabila nilai pearson correlation lebih dari 0,30. Hasil uji validitas dari penelitian ini disajikan dalam Tabel 3, Hasil uji validitas dalam penelitian ini menunjukkan seluruh item pertanyaan kuisioner adalah valid, karena dapat terlihat dari nilai pearson correlation yang lebih besar dari 0,30 .

\section{Tabel 2. Hasil Uji Validitas}

\begin{tabular}{llll}
\hline Variabel & Instrumen & Pearson Correlation & Keterangan \\
\hline Penerapan E-Filing & X1-X12 & $0,537-0,699$ & Valid \\
Sosialisasi Perpajakan & Z1.1-Z1.4 & $0,772-0,702$ & Valid \\
Pemahaman Internet & Z2.1-Z2.6 & $0,842-0,846$ & Vallid \\
Kepatuhan Wajib Pajak & Y1-Y8 & $0,776-0,732$ & Valid \\
\hline
\end{tabular}

Sumber: Data Penelitian, 2019

Pengujian reabilitas atau keandalan instrumen menunjukan sejauh mana suatu pengukuran dapat memberikan hasil yang konsistem bila dilakukan pengukuran kembali. Variabel dikatakan realiabel apabila nilai cronchbach's alpha $>0,70$. Hasil uji reabilitas disajikan pada Tabel 3.

Tabel 3. Hasil Uji Reabilitas

\begin{tabular}{lll}
\hline Variabel & Cronchbach's alpha & Keterangan \\
\hline Penerapan E-Filing & 0,898 & Realiabel \\
Sosialisasi Perpajakan & 0,731 & Realiabel \\
Pemahaman Internet & 0,912 & Realiabel \\
Kepatuhan Wajib Pajak Orang Pribadi & 0,895 & Realiabel \\
\hline
\end{tabular}

Sumber: Data Penelitian, 2019

Dari hasil uji reabilitas yang disajikan pada Tabel 3, Hasil Uji Reabilitas, maka dapat disimpulkan bahwa seluruh variabel yang digunakan dalam penelitian ini adalah reliabel. Seluruh variabel memiliki nilai cronchbach alpha $>0,70$, sehingga pernyataan kuisioner dalam penelitian ini layak digunakan menjadi alat ukur instrumen penelitian.

Statistik deskriptif digunakan untuk memberikan informasi menggambarkan atau mendeskripsikan karakteristik atau sifat-sifat yang dimiliki oleh sampel. Statistik deskriptif dilihat dari rata - rata (mean), standar deviasi (standard deviation) dan maksimum - minimum. 
YANTI, P. L. P. \& SETIAWAN, P. E.

Tabel 4. Hasil Uji Statistik Deskriptif

\begin{tabular}{|c|c|c|c|c|c|}
\hline & $\mathrm{N}$ & Minimum & Maximum & Mean & $\begin{array}{l}\text { Std. } \\
\text { Deviation }\end{array}$ \\
\hline $\begin{array}{l}\text { Kepatuhan } \\
\text { WPOP }\end{array}$ & 100 & 28,00 & 40,00 & 34,4600 & 3,51740 \\
\hline $\begin{array}{l}\text { Penerapan E- } \\
\text { Filing }\end{array}$ & 100 & 40,00 & 60,00 & 51,5200 & 4,76621 \\
\hline $\begin{array}{l}\text { Sosialisasi } \\
\text { Perpajakan }\end{array}$ & 100 & 12,00 & 20,00 & 16,5600 & 1,78275 \\
\hline $\begin{array}{l}\text { Pemahaman } \\
\text { Internet }\end{array}$ & 100 & 21,00 & 30,00 & 26,6100 & 2,48996 \\
\hline $\begin{array}{ll}\text { Valid } & \mathrm{N} \\
\text { (listwise) } & \end{array}$ & 100 & & & & \\
\hline
\end{tabular}

Sumber: Data Penelitian, 2019

Berdasarkan Tabel 4, Hasil Uji Statistik Deskriptif, dapat disimpulkan bahwa jumlah pengamatan $(\mathrm{N})$ dalam penelitian ini berjumlah 100. Variabel penerapan e-filing $(\mathrm{X})$ memiliki nilai terendah sebesar 28,00 dan nilai tertinggi sebesar 40,00 dengan rata- rata sebesar 36,46. Standar deviasi untuk penerapan $e-$ filing sebesar 3,517, artinya terjadi perbedaan nilai penerapan e-filing terhadap nilai rata ratanya sebesar 3,517.

Variabel sosialisasi perpajakan $\left(Z_{1}\right)$ memiliki nilai terendah sebesar 12,00 dan nilai tertinggi sebesar 20,00 dengan rata-rata sebesar 16,56 . Standar deviasi untuk sosialisasi perpajakan sebesar 1,782, artinya terjadi perbedaan nilai sosialisasi perpajakan terhadap nilai rata ratanya sebesar 1,782.

Variabel pemahaman internet $\left(Z_{2}\right)$ memiliki nilai terendah sebesar 21,00 dan nilai tertinggi sebesar 30,00 dengan rata-rata sebesar 26,61. Standar deviasi untuk pemahaman internet sebesar 2,489, artinya terjadi perbedaan nilai pemahaman internet terhadap nilai rata ratanya sebesar 2,489.

Variabel Kepatuhan Wajib Pajak Orang Pribadi (Y) memiliki nilai terendah sebesar 28,00 dan nilai tertinggi sebesar 40,00 dengan rata- rata sebesar 34,46. Standar deviasi untuk Kepatuhan Wajib Pajak Orang Pribadi sebesar 3,517, artinya terjadi perbedaan nilai Kepatuhan Wajib Pajak Orang Pribadi terhadap nilai rata ratanya sebesar 3,517 .

Uji normalitas bertujuan untuk mengetahui apakah residual dari model regresi yang dibuat berdistribusi normal atau tidak. Jika probabilitas signifikansi nilai residual lebih besar dari 0,05 maka data tersebut dikatakan berdistribusi normal.

Tabel 5. Hasil Uji Normalitas

\begin{tabular}{ll}
\hline & Unstandarized Residual \\
\hline $\mathrm{N}$ & 100 \\
Asymp. Sig. (2-tailed) & 0,420 \\
\hline Sumber: Data Penelitian, 2019 & \\
Berdasarkan hasil analisis pada Tabel 5, Hasil Uji Normalitas, didapat \\
nilai signifikansi sebesar 0,420 yang lebih besar dari 0,05 maka dapat \\
disimpulkan bahwa model persamaan regresi dalam penelitian ini berdistribusi \\
normal.
\end{tabular}

Uji heteroskedastisitas bertujuan untuk mengetahui model apakah dalam model regresi terjadi ketidaksamaan varians residual satu pengamatan ke 
pengamatan lain yang dilakukan dengan uji Glejser. Jika variabel bebas yang diteliti tidak mempunyai pengaruh signifikan atau nilai signifikasninya lebih dari 0,05 terhadap nilai absolute residual, berarti model regresi tidak mengandung gejala heteroskedastisitas.

Tabel 6. Hasil Uji Heteroskedastisitas

\begin{tabular}{|c|c|c|c|c|c|c|}
\hline \multirow{2}{*}{\multicolumn{2}{|c|}{ Model }} & \multicolumn{3}{|c|}{$\begin{array}{r}\text { Unstandardized Coefficients Standardized } \\
\text { Coefficients }\end{array}$} & \multirow[t]{2}{*}{$\mathrm{t}$} & \multirow[t]{2}{*}{ Sig. } \\
\hline & & B & Std. Error & Beta & & \\
\hline \multirow{6}{*}{1} & (Constant) & $-9,333$ & 22,125 & & $-0,422$ & 0,674 \\
\hline & Penerapan E-Filing & 0,327 & 0,418 & 1,011 & 0,783 & 0,436 \\
\hline & Sosialisasi Perpajakar & 0,117 & 1,049 & 0,135 & 0,112 & 0,911 \\
\hline & Pemahaman Internet & 0,240 & 0,826 & 0,387 & 0,290 & 0,772 \\
\hline & X.Z1 & $-0,009$ & 0,020 & $-0,844$ & $-0,437$ & 0,663 \\
\hline & X.Z2 & $-0,005$ & 0,016 & $-0,725$ & $-0,295$ & 0,769 \\
\hline
\end{tabular}

Sumber: Data Penelitian, 2019

Berdasarkan Tabel 6, Hasil Uji Heteroskedastisitas, nilai signifikansi dari masing - masing variabel nilainya melebihi 0,05 . Hal ini menunjukkan bahwa model regresi dalam penelitian ini bebas dari gejala heteroskedastisitas. Hasil uji heteroskedastisitas disajikan pada Tabel 6.

Analisis regresi linier sederhana digunakan untuk mengetahui perubahan yang terjadi pada variabel dependent (variabel Y), nilai variabel dependent berdasarkan nilai independent (variabel $X$ ) yang diketahui dengan menggunakan tingkat signifikan sebesar 0,05. Hasil uji regresi linear sederhana terhadap variabel independennya yaitu kepatuhan Wajib Pajak.

Tabel 7. Hasil Uji Regresi Sederhana

\begin{tabular}{|c|c|c|c|c|c|}
\hline \multirow[t]{2}{*}{ Model } & \multicolumn{2}{|c|}{$\begin{array}{l}\text { Unstandarized } \\
\text { Coefficient }\end{array}$} & $\begin{array}{l}\text { Standarized } \\
\text { Coefficients }\end{array}$ & \multirow[t]{2}{*}{$\mathrm{t}$} & \multirow[t]{2}{*}{ Sig } \\
\hline & B & Std. Error & Beta & & \\
\hline (Constant) & 8,022 & 2,722 & & 2,894 & 0,005 \\
\hline Penerapan & 0,513 & 0,54 & 0,695 & 9,578 & 0,000 \\
\hline E-Filing & & & & & \\
\hline $\mathrm{R}$ & 0,695 & & & & \\
\hline $\mathrm{R}^{2}$ & 0,484 & & & & \\
\hline Adjusted $R^{2}$ & 0,478 & & & & \\
\hline F Hitung & 91,744 & & & & \\
\hline Sig.F & 0,000 & & & & \\
\hline
\end{tabular}

Sumber : Data Penelitian, 2019

Nilai kontanta $(\alpha)$ sebesar 8,022. Hal ini menunjukkan bahwa bila penerapan e-filing $(X)$ sama dengan nol, maka kepatuhan Wajib Pajak Orang Pribadi (Y) akan meningkat sebesar 8,022 satuan.

Nilai koefisien $\left(\beta_{\mathrm{x}}\right)$ dari variabel penerapan e-filing sebesar 0,513 . Hal ini menunjukkan bila penerapan e-filing $(X)$ bertambah 1 satuan, maka nilai dari kepatuhan Wajib Pajak Orang Pribadi (Y) akan mengalami peningkatan sebesar 0,513 satuan dengan asumsi variabel bebas lainnya konstan. Berdasarkan hasil analisis regresi linear sederhana, selanjutnya dapat diamati uji goodness of fit (uji kecocokan) dengan melihat koefisien determinasi $\left(R^{2}\right)$, uji kelayakan model (uji F) dan uji hipotesis (uji t), yaitu sebagai berikut. 
Koefisien determinasi digunakan untuk mengukur sejauh mana kemampuan variabel independen dalam menerangkan variasi variabel dependen. Berdasarkan Tabel 7, Hasil Uji Regresi Sederhana, dapat dilihat angka adjusted $r$ square sebesar 0,484 atau 48,4 persen yang menunjukan bahwa 48,4 persen variabel kepatuhan Wajib Pajak Orang Pribadi yang bisa dijelaskan oleh variabel penerapan e-filing, sisanya 51,6 persen dijelaskan oleh faktor lain.

Uji F kelayakan model (Uji F) digunakan untuk mengetahui apakah variabel bebas yang diidentifikasi (e-filing) tepat digunakan untuk memprediksi kepatuhan Wajib Pajak. Berdasarkan Tabel 7, nilai signifikansi yang diperoleh adalah sebesar 0,000 yang lebih kecil dari a=0,05. Maka dapat disimpulkan bahwa penerapan e-filing, sosialisasi perpajakan dan pemahaman internet mampu menjelaskan kepatuhan Wajib Pajak Orang Pribadi di KPP Pratama Badung Utara.

Uji hipotesis (uji statistik t) bertujuan untuk melihat ada tidaknya pengaruh variabel bebas (penerapan e-filing) terhadap variabel terikat (kepatuhan Wajib Pajak Orang Pribadi). Uji statistik t menjawab hipotesis yang dikembangkan didalam penelitian ini. Berdasarkan Tabel 7, Hasil Uji Regresi Sederhana, disajikan hasil nilai dari $\beta_{\mathrm{x}}$ adalah seber 0,513 serta nilai signifikansi sebesar $0,000<0,05$. Nilai tersebut menyatakan bahwa variabel penerapan $e$-filing berpengaruh positif dan signifikan pada variabel kepatuhan Wajib Pajak dan artinya hipotesis pertama $\left(\mathrm{H}_{1}\right)$ diterima yaitu penerapan e-filing berpengaruh positif pada kepatuhan Wajib Pajak Orang Pribadi di KPP Pratama Badung Utara. Hasil penelitian ini didukung oleh penelitian yang dilakukan oleh Marliana et al., (2017), Agustiningsih (2016), Lado \& Budiantara (2018) dan Sari \& Erawati (2018) yang menyatakan bahwa penerapan e-filing berpengaruh positif pada kepatuhan Wajib Pajak Orang Pribadi.

Moderated Regression Analysis (MRA) merupakan teknik analisis data dimana dalam persamaan regresinya mengandung unsur interaksi (perkalian dua atau lebih variabel independen), teknik analisis ini dipilih karena penelitian ini dirancang untuk meneliti variabel independen yang berpengaruh terhadap variabel dependen dengan menggunakan variabel moderasi.

Tabel 8. Hasil Uji Moderated Regression Analysis

\begin{tabular}{|c|c|c|c|c|c|c|}
\hline \multirow{2}{*}{\multicolumn{2}{|c|}{ Model }} & \multicolumn{3}{|c|}{$\begin{array}{r}\text { Unstandardized CoefficientsStandardized } \\
\text { Coefficients }\end{array}$} & \multirow[t]{2}{*}{$\mathrm{t}$} & \multirow[t]{2}{*}{ Sig. } \\
\hline & & $\mathrm{B}$ & Std. Error & Beta & & \\
\hline \multirow{10}{*}{1} & (Constant) & $-15,546$ & 37,059 & & $-0,420$ & 0,676 \\
\hline & Penerapan E-Filing & 1,152 & 0,700 & 1,561 & 1,647 & 0,103 \\
\hline & Sosialisasi Perpajakan & $-2,087$ & 1,756 & $-1,058$ & $-1,188$ & 0,238 \\
\hline & Pemahaman Internet & 1,948 & 1,384 & 1,379 & 1,408 & 0,162 \\
\hline & X.Z1 & 0,043 & 0,033 & 1,827 & 1,288 & 0,201 \\
\hline & X.Z2 & $-0,046$ & 0,027 & $-3,074$ & $-1,700$ & 0,092 \\
\hline & $\mathrm{R}$ & 0,736 & & & & \\
\hline & $\mathrm{R}^{2}$ & 0,541 & & & & \\
\hline & F Hitung & 22.198 & & & & \\
\hline & Sig. F & 0,000 & & & & \\
\hline
\end{tabular}

Sumber: Data Penelitian, 2019 
Nilai kontanta $(\alpha)$ sebesar $-15,546$ menunjukkan bahwa bila penerapan $e^{-}$ filing $(X)$, pemahaman internet $(Z)$, interaksi penerapan e-filing dengan sosialisasi perpajakan $\left(\mathrm{XZ}_{1}\right)$ dan interaksi penerapan $e$-filing dengan pemahaman internet $\left(X_{2}\right)$ sama dengan nol, maka kepatuhan Wajib Pajak Orang Pribadi (Y) akan menurun sebesar 15,546 satuan.

Nilai koefisien $\beta_{1}=1,152$. Hal ini menunjukkan bila penerapan e-filing $(X)$ bertambah 1 satuan, maka nilai dari kepatuhan Wajib Pajak Orang Pribadi (Y) akan mengalami peningkatan sebesar 1,152 satuan dengan asumsi variabel bebas lainnya konstan.

Nilai koefisien $\beta_{2}=-2,087$ memiliki arti bahwa bila sosialisasi perpajakan $\left(Z_{1}\right)$ bertambah 1 satuan, maka nilai dari kepatuhan Wajib Pajak Orang Pribadi (Y) akan mengalami penurunan sebesar 2,087 satuan asumsi variabel bebas lainnya konstan.

Nilai koefisien $\beta_{3}=1,948$. Hal ini menunjukkan bila pemahaman internet $\left(Z_{2}\right)$ bertambah 1 satuan, maka nilai dari kepatuhan Wajib Pajak Orang Pribadi (Y) akan mengalami peningkatan sebesar 1,948 satuan dengan asumsi variabel bebas lainnya konstan.

Nilai koefisien $\beta_{4}=0,043$ memiliki arti bahwa nilai interaksi antara penerapan e-filing dengan sosialisasi perpajakan $\left(\mathrm{Z}_{1}\right)$ meningkat satu satuan, maka kepatuhan Wajib Pajak Orang Pribadi akan meningkat sebesar 0,043 satuan.

Nilai koefisien $\beta_{5}=-0,046$ memiliki arti bahwa nilai interaksi antara penerapan $e$-filing dengan pemahaman internet $\left(Z_{2}\right)$ meningkat satu satuan, maka kepatuhan Wajib Pajak Orang Pribadi akan menurun sebesar 0,46 satuan.

Beradasarkan hasil analisis Moderated Regression Analysis (MRA) selanjutnya dapat diamati goodness of fit (uji kecocokan) dengan melihat koefisien determinasi $\left(R^{2}\right)$, uji kelayakan model (uji F) dan uji hipotesis (uji t), yaitu sebagai berikut.

Berdasarkan Tabel 8, Hasil Uji Moderated Regression Analysis, Hasil Uji Moderated Regression Analysis, nilai koefisien determinasi $\left(R^{2}\right)$ sebesar 0,541 atau 54,1 persen yang didilhat dari nilai adjusted $R$ square. Nilai adjusted $R$ square sebesar 51,7 persen menunjukan bahwa 51,7 persen variabel Kepatuhan Wajib Pajak Orang Pribadi yang bisa dijelaskan oleh variabel penerapan $e$-filing, sisanya 48,3 persen dijelaskan oleh faktor lain.

Uji F digunakan untuk mengetahui kelayakan dari model regresi sebagai alat analisis yang menguji pengaruh variabel independen terhadap variabel dependen. Dari Tabel 8, dapat dilihat bahwa nilai signifikansi adalah sebesar 0,000 yang lebih kecil dari a =0,05. Maka dapat disimpulkan bahwa penerapan $e$ filing, sosialisasi perpajakan dan pemahaman internet mampu menjelaskan kepatuhan Wajib Pajak Orang Pribadi di KPP Pratama Badung Utara.

Hasil uji parsial (uji t) yang disajikan pada Tabel 8, Hasil Uji Moderated Regression Analysis, menunjukkan bahwa $\beta_{4}=0,043$ dengan tingkat signifikansi sebesar 0,201 yang berarti lebih besar daripada tingkat signifikansi dalam penelitian ini yaitu 0,05 . Hal ini memiliki arti bahwa hipotesis kedua $\left(\mathrm{H}_{2}\right)$ dalam penelitian ini ditolak. Hasil ini tidak mendukung hipotesis yang diajukan bahwa sosialisasi perpajakan dapat memoderasi pengaruh penerapan e-filing pada kepatuhan Wajib Pajak Orang Pribadi di KPP Pratama Badung Utara. Hal ini 
disebabkan karena Wajib Pajak Orang Pribadi yang sudah dapat mengaplikasikan system $e$-filing, mereka secara umum sudah mengatahui teknis penggunaan sistem e-filing. Hasil penelitian ini sejalan dengan penelitian yang dilakukan oleh Setiyarini (2017), Gustiari \& Suprasto (2018) dan Handayani \& Tambun (2016) yang menyatakan bahwa sosialisasi perpajakan tidak dapat memoderasi pengaruh hubungan penerapan sistem e-filing pada kepatuhan Wajib Pajak.

Hasil uji parsial (uji t) yang disajikan pada Tabel 8, Hasil Uji Moderated Regression Analysis, menunjukkan bahwa $\beta_{5}=-0,046$ dengan tingkat signifikansi sebesar 0,092 yang berarti lebih besar daripada tingkat signifikansi dalam penelitian ini yaitu 0,05 . Hal ini memiliki arti bahwa hipotesis ketiga $\left(\mathrm{H}_{3}\right)$ dalam penelitian ini ditolak. Hasil pengujian ini tidak mendukung hipotesis yang diajukan bahwa pemahaman internet dapat memoderasi pengaruh penerapan $e$ filing pada kepatuhan Wajib Pajak Orang Pribadi di KPP Pratama Badung Utara. Hal ini disebabkan karena walaupun Wajib Pajak memiliki pemahaman internet yang baik, penyampaian SPT melalui sistem penerapan e-filing masih dapat dilakukan oleh siapa saja sehingga Wajib Pajak Orang Pribadi yang tidak paham maupun paham internet dengan baik dapat meminta bantuan orang lain misalnya konsultan pajak untuk melaporkan SPTnya secara online menggunakan sistem $e$-filing. Hasil penelitian ini sejalan dengan penelitian yang dilakukan oleh Agniveda \& Supadmi (2019) dan Lado \& Budiantara (2018) yang menunjukkan pemahaman internet tidak dapat memoderasi pengaruh penerapan sistem e-filing pada kepatuhan Wajib Pajak Orang Pribadi.

\section{SIMPULAN}

Hasil penelitian ini memberikan tambahan informasi mengenai bagaimana penerapan $e$-filing, pemahaman internet dan sosialisasi perpajakan memengaruhi kepatuhan Wajib Pajak Orang Pribadi. Terdapat bukti empiris yang diperoleh dari penelitian ini yang menunjukkan bahwa penerapan e-filing berpengaruh pada kepatuhan Wajib Pajak Orang Pribadi. Hal ini didukung dengan adanya Technologi Acceptance Model (TAM) menyatakan bahwa persepsi kemudahan dan persepsi kegunaan adalah yang akan menjadi penentu dari suatu sistem dapat diterima atau tidak. Wajib Pajak yang beranggapan bahwa sistem e-filing itu mudah digunakan dan Wajib Pajak percaya bahwa menggunakan sistem $e$-filing akan membantu dalam penyerahan SPT maka hal ini akan meningkatkan kepatuhan Wajib Pajak dalam melaporkan SPT, sehingga jika Wajib Pajak dalam menyampaikan SPT tahunan diberikan kemudahan, kenyamanan dan keamanan dari program e-filing, maka Wajib Pajak akan patuh dalam melakukan penyampaian SPT tahunan.

Adapun saran yang dapat diberikan pada penelitian ini adalah Bagi pihak KPP Pratama Badung Utara diharapkan agar lebih gencar dalam melakukan sosialisasi secara langsung dan berkesinambungan kepada Wajib Pajak KPP Pratama Badung Utara terkait penerapan sistem e-filing, agar sistem tersebut dapat dimanfaatkan lebih baik lagi untuk memenuhi kewajiban perpajakan. Selain itu, diperlukan juga adanya peningkatkan kualitas helpdesk di KPP Pratama Badung Utara yang akan mengakomodasikan Wajib Pajak yang mengalami masalah dalam menggunakan sistem $e$-filing. 


\section{REFERENSI}

Agniveda, I. G. N. A. P. A., \& Supadmi, N. L. (2019). Pengaruh Penerapan EFilling Pada Kepatuhan WPOP Pegawai Negeri Sipil Dengan Pemahaman Internet Sebagai Variabel Pemoderasi, 28, 242-269.

Agustiningsih, W. (2016). Pengaruh Penerapan E-Filing, Tingkat Pemahaman Perpajakan Dan Kesadaran Wajib Pajak Terhadap Kepatuhan Wajib Pajak Di KPP Pratama Yogyakarta. Nominal, V(4).

Ameur, F., \& Tkiouat, M. (2016). A Contribution of Expected Utility Theory in Taxpayers' Behavior Modeling. International Journal of Economics and Financial Issues, 6(3), 1217-1224.

Anees;, D. M., \& Kumar, M. M. (2017). Perception of Taxpayers' Towards E-file Adoption. International Journal of Research - Granthaalayah, 5(11), 325-332. https://doi.org/10.5281/zenodo.1117173

Chau, G., \& Leung, P. (2009). A Critical Review Of Fischer Tax Compliance Model: A Research Synthesis. Journal of Accounting and Taxation, 1(2), 034040. https://doi.org/10.5897/JAT09.021

Davis, J. S., Hecht, G., \& Perkins, J. D. (2003). Social Behaviors, Enforcement, and Tax Compliance Dynamics. Accounting Review, 78(1), 39-69. https:// doi.org/10.2308/accr.2003.78.1.39

Devos, K. (2009). An Investigation Into Australian Personal Tax Evaders- Their Attitudes Towards Compliance And The Penalties For Non-Compliance An Investigation Into Australian Personal Tax Evaders- Their Attitudes. Revenue Law Journal, 19(1), Article 2.

Gefen, D. (2003). TAM Or Just Plain Habit: A Look At Experienced Online Shoppers. Journal of End User Computing, 15(3), 1-13. https:// doi.org/10.4018/joeuc.2003070101

Gustiari, L. A., \& Suprasto, H. B. (2018). Sosialisasi Perpajakan Memoderasi Pengaruh Kewajiban Moral dan Kualitas Pelayanan pada Kepatuhan Wajib Pajak Kendaraan Bermotor. E-Jurnal Akuntansi, 24, 606. https:// doi.org/10.24843/EJA.2018.v24.i01.p23

Hammar, H., Jagers, S. C., \& Nordblom, K. (2009). Perceived Tax Evasion And The Importance Of Trust. Journal of Socio-Economics, 38(2), 238-245. https:// doi.org/10.1016/j.socec.2008.07.003

Handayani, K. R., \& Tambun, S. (2016). Pengaruh Penerapan Sistem E-Filing Dan Pengetahuan Perpajakan Terhadap Kepatuhan Wajib Pajak Dengan Sosialisasi Sebagai Variabel Moderating. Journal UTA45JAKARTA, 1(2), 5973.

Helhel, Y. \&, \& Ahmed, Y. (2014). Factors Affecting Tax Attitudes and Tax Compliance: A Survey Study in Yemen. European Journal of Business and Management Online ), 6(22), 2222-2839.

Ida Ayu Candra Apsari Manuaba, \& Gayatri, G. (2017). Pengaruh Pengetahuan Pemahaman Peraturan Pajak, Pelayanan Fiskus, Persepsi Efektivitas Sistem Perpajakan Terhadap Kemauan Membayar Pajak. E-Jurnal Akuntansi Universitas Udayana, 19, 1259-1289. Retrieved from https://ojs.unud.ac.id/index.php/Akuntansi/article/view/27901

Indri Setiyarini, M. (2017). Pengaruh Penerapan Sistem E-Filing, Pengetahuan Perpajakan Terhadap Kepatuhan Wajib Pajak Dengan Sosialisasi Perpajakan 
Sebagai Variabel Moderating. ABA Journal, 102(4), 24-25. https:// doi.org/10.1002/ ejsp.2570

Ismail, J., \& Amalo, F. (2018). Pengaruh Penerapan Sistem E - Filing Terhadap Kepatuhan Wajib Pajak Dengan Sosialisasi Sebagai Variabel Moderasi (Studi Kasus Pada KPP Pratama Kupang). Jurnal Akuntansi (JA), 5(3), 11-22.

Kirchler, E., \& Wahl, I. (2010). Tax Compliance Inventory Tax-I Voluntary Tax Compliance, Enforced Tax Compliance, Tax Avoidance, And Tax Evasion. Journal of Economic Psychology, 31(3), 331-346. https:// doi.org/10.1016/j.joep.2010.01.002

Lado, Y. O., \& Budiantara, M. (2018). Pengaruh Penerapan Sistem E-Filling Terhadap Kepatuhan Wajib Pajak Orang Pribadi Pegawai Negeri Sipil Dengan Pemahaman Internet Sebagai Variabel Pemoderasi (Studi Kasus pada Dinas Perindustrian dan Perdagangan DIY). Jurnal Riset Akuntansi Mercu Buana, 4(1), 59. https://doi.org/10.26486/jramb.v4i1.498

Marliana, R., Suherman, M., \& Almunawwaroh, M. (2017). Pengaruh Penerapan E-filing Terhadap Kepatuhan Wajib Pajak Dalam Penyampaian Surat Pemberitahuan (SPT) Tahunan Pada Kantor Pelayanan Pajak Pratama Kota Tasikmalaya, 15(1), 49-64. https:// doi.org/10.25105/mraai.v15i1.1649

Paramartha, I. P. I. P., \& Rasmini, N. K. (2019). Pengaruh Kualitas Pelayanan, Pengetahuan Dan Sanksi Perpajakan Pada Kepatuhan Wajib Pajak Badan. EJurnal Akuntansi, 15, 748. https://doi.org/10.24843/ eja.2019.v28.i01.p29

Pranata, K. K., \& Supadmi, N. L. (2018). Pengaruh Penerapan E-Filing pada Kepatuhan Wajib Pajak Badan dengan Biaya Kepatuhan Pajak sebagai Variabel Moderasi. E-Jurnal Akuntansi, 24, 633. https:// doi.org/10.24843/eja.2018.v24.i01.p24

Putu Dessy Kurnia Dewi, \& Naniek Noviari. (2018). Faktor-Faktor yang Memengaruhi Intensitas Perilaku dalam Penggunaan E-Filing Pada Wajib Pajak Orang Pribadi, 22, 2368-2397.

Sari, R. R., \& Erawati, T. (2018). Pengaruh Penerapan Efiling Terhadap Kepatuhan Wajib Pajak Dalam Menyampaikan SPT Tahunan Dengan Kepuasan Kualitas Pelayanan Sebagai Variabel Intervening. Jurnal Akuntansi, 6(1), 1-10. https:// doi.org/10.24964/ja.v6i1.427

Suprayogo, S., \& Hasymi, M. (2018). Pengaruh Penerapan Sistem E-Filing Terhadap Kepatuhan Wajib Pajak Orang Pribadi Dengan Pemahaman Internet Sebagai Variabel Moderasi Pada Kantor Pelayanan Pajak Pratama $\begin{array}{llll}\text { Jakarta Jatinegara. Jurnal Profita, } 11(2), & 151 .\end{array}$ https:// doi.org/10.22441/profita.2018.v11.02.001

Suriambawa, A., \& Ery Setiawan, P. (2018). Sosialisasi Perpajakan Memoderasi Pengaruh Kesadaran Wajib Pajak dan Sanksi Perpajakan Pada Kepatuhan WPOP. E-Jurnal Akuntansi, 2185. https:// doi.org/10.24843/eja.2018.v25.i03.p21

Venkatesh, V., \& Davis, F. D. (2000). A Theoretical Extension of the Technology Acceptance Model Four Longitudinal Field Studies. Management Science, 46(2), 186-204. https:// doi.org/10.1287/mnsc.46.2.186.11926

Walsh, K. (2012). Understanding taxpayer behaviour - new opportunities for tax administration. Economic and Social Review, 43(3), 451-475.

Wardani, D. K., \& Wati, E. (2018). Pengaruh Sosialisasi Perpajakan Terhadap 
Kepatuhan Wajib Pajak Dengan Pengetahuan Perpajakan Sebagai Variabel Intervening (Studi Pada Wajib Pajak Orang Pribadi di KPP Pratama Kebumen). Nominal, Barometer Riset Akuntansi Dan Manajemen, 7(1). https:// doi.org/10.21831/nominal.v7i1.19358

Wilberforce Serem, Kinanga Robert, O. P. (2017). The Effect Of Tax System Simplicity On Tax Compliance Among The Rental Income Earners In Kenya. A Case Of Eldoret Central Business District. European Centre for Research Training and Development UK,

$(1)$,

43. https:// doi.org/10.1017/CBO9781107415324.004 